\title{
SURAT KUASA MEMASANG HIPOTEK DALAM JAMINAN HIPOTEK KAPAL LAUT
}

\author{
Fani Martiawan Kumara Putra \\ Fakultas Hukum Universitas Airlangga Surabaya \\ e-mail: fanimartiawan@gmail.com
}

\begin{abstract}
ABSTRAK
Pembebanan hipotek atas kapal laut dilakukan dengan menggunakan akta otentik, pembuatan akta otentik jaminan hipotek adalah kewenangan dari Pejabat Pendaftar dan Pencatat Balik Nama Kapal sebagaimana telah ditunjuk oleh undang-undang. Faktual, pembebanan hipotek selalu dilakukan dengan pembuatan Surat Kuasa Memasang Hipotek yang berisi janji-janji terlebih dahulu. Walaupun tidak diwajibkan, Surat Kuasa Memasang Hipotek dirasa oleh masyarakat dapat lebih menjembatani dan melindungi kepentingan para pihak. Hipotek merupakan jaminan kebendaan, maka harus memenuhi asas publisitas, yaitu dengan mendaftarkan jaminan hipotek tersebut dalam register umum yang sifatnya terbuka. Pemenuhan asas publisitas ini akan membawa implikasi kepada pihak ketiga di luar perjanjian jaminan hipotek tersebut.
\end{abstract}

Kata Kunci: Surat Kuasa Memasang Hipotek, hipotek, kapal laut.

\begin{abstract}
The imposition of a ship mortgage should be done by using an authentic deed, the making of motrtgage's deed is the authority of Pejabat Pendaftar dan Pencatat Balik Nama Kapal as it is designated by the law. Factually before the parties go to the Pejabat Pendaftar dan Pencatat Balik Nama Kapal for the imposition of a ship mortgage they will go to the notary to make such an attonery, which called Surat Kuasa Memasang Hipotek that contains some promises and agreements made and agreed by the parties. Eventhough this Surat Kuasa Memasang Hipotek is not a must but the substance of this deed could even more in giving protection and could accommodate the willingness of the parties, and also give more protection to the parties. Ship mortgage is a property rights guarantee, thats why it must fulfil the publicity principle which is done by registering the mortgage into the general register.
\end{abstract}

Keywords: Mortgage's Deed, Mortgage, ship mortgage, hypotheek.

\section{PENDAHULUAN}

Perkembangan juga pembangunan perekonomian di Indonesia dewasa ini dapat dikatakan sebagai bagian dari pembangunan nasional yang berupaya untuk mewujudkan masyarakat adil dan makmur. Pembangunan perekonomian dapat juga terlihat dari meluasnya bidang usaha di antara masyarakat, dan dengan semakin meluasnya bidang usaha, disertai dengan semakin banyaknya sumber daya manusia dan demi memelihara keseimbangan dan kelanjutan pembangunan, maka pelaku usaha baik itu pemerintah maupun masyarakat sebagai orang perorangan dan badan hukum, sangat memerlukan dana dalam jumlah yang terbilang sangat besar.

Upaya akan pemenuhan kebutuhan dana yang sangat besar ini sangatlah didukung oleh kegiatan perkreditan, hadirnya dan juga terus berkembangnya kegiatan perkreditan di tengah maraknya bidangbidang usaha yang sedang berkembang dewasa ini, menunjukkan bahwa kredit merupakan salah satu sumber pembiayaan yang mempunyai peranan sangat penting dalam era pembangunan sekarang ini.

Menyadari bahwa dana yang keluar dan masuk dalam kegiatan perkreditan itu adalah dana yang sangat besar, dan dengan didasari atas pentingnya dan sungguh beresikonya kegiatan perkreditan itu, maka sudah semestinya kegiatan perkreditan tersebut didampingi dengan kegiatan penjaminan, karena perkembangan ekonomi dan juga perdagangan yang diikuti oleh perkembangan kebutuhan akan kredit dan pemberian fasilitas kredit ini memerlukan jaminan demi keamanan (Sri Soedewi Machsoen S., 1980:1). Maka sudah sepantasnya jika pemberi dan penerima kredit, serta pihak lain yang juga terkait dalam suatu kegiatan perkreditan mendapat perlindungan melalui suatu lembaga jaminan yang mana dapat memberikan kepastian hukum bagi semua pihak tersebut. 
Salah satu bentuk kegiatan usaha di Indonesia yang tidak lepas dari kegiatan perkreditan dan perlunya penjaminan, adalah kegiatan yang berkaitan dengan kapal laut, yaitu kegiatan pelayaran, tentu saja hal ini karena Indonesia merupakan negara kepulauan. Republik Indonesia merupakan negara kepulauan yang memiliki dua pertiga wilayah laut dibandingkan dengan seluruh daratan pulau atau kurang lebihnya luas wilayah laut seluas $3.166,163 \mathrm{~km}^{2}$, sedangkan luas wilayah daratan pulau seluas $2.027 .087 \mathrm{~km}^{2}$ (Etty R. Agoes, 1991:164). Dengan kata lain, bahwa duapertiga dari seluruh wilayah Indonesia merupakan lautan. Pelayaran merupakan tatanan transportasi laut yang mempunyai karakteristik sebagai penghubung wilayah baik antara daerah satu dengan daerah yang lainnya, maupun negara satu dengan negara yang lainnya dalam lalu-lintas perdagangan internasional. Dengan fakta ini, maka dalam menanggapi kebutuhan yang berkembang di masyarakat, pemerintah telah mengeluarkan berbagai kebijakan, dan dalam hal perkreditan ini yang menjadi perhatian serius adalah lembaga jaminan, yang diatur dalam hukum jaminan.

Istilah hukum jaminan berasal dari terjemahan zakerheidestelling atau security of law. Sri Soedewi Masjhoen Sofwan mengemukakan bahwa hukum jaminan itu mengatur akan konstruksi yuridis yang memungkinkan pemberian fasilitas kredit, dengan menjaminkan benda-benda yang dibelinya sebagai jaminan. Peraturan demikian harus cukup meyakinkan dan memberikan kepastian hukum bagi lembagalembaga kredit, baik dari dalam maupun luar negeri. Adanya lembaga jaminan dan lembaga demikian kiranya harus dibarengi dengan adanya lembaga kredit dengan jumlah, besar, dengan jangka waktu yang lama dan bunga yang relatif rendah (Sri Soedewi Masjhoen Sofwan, 1980:5)

Menurut J. Satrio, hukum jaminan merupakan peraturan hukum yang mengatur jaminan-jaminan piutang seorang kreditor terhadap debitor (J. Satrio, 1996:3). Sementara Salim H.S. menarik kesimpulan dari kedua pendapat tentang jaminan di atas dengan definisi dari hukum jaminan adalah keseluruhan dari kaidah-kaidah hukum yang mengatur hubungan hukum antara pemberi jaminan dan penerima jaminan, dalam kaitannya dengan pemberian jaminan untuk mendapatkan fasilitas kredit (Salim H.S., 2008:6).

Sesuai namanya, yaitu jaminan, maka dibutuhkan untuk adanya suatu benda yang akan dijaminkan demi mendapatkan dana dari penjamin (kreditor), lembaga penjaminan yang telah dikenal sejak adanya Burgerlijk Wetboek (yang selanjutnya disebut BW) antara lain yaitu gadai. Kapal laut yang menjadi pemikiran dalam penulisan ini, tentunya para pelaku usahanya juga memerlukan dana yang besar, dan dengan didampinginya kegiatan perkreditan dengan penjaminan gadai, maka para pelaku usaha yang sesungguhnya hanya mempunyai kapal sebagai benda yang dapat dijaminkan, usahanya akan terhenti bila kapal tersebut dijaminkan demi keluarnya dana dari kreditor, hal mana sudah barang tentu bila dijaminkan melalui lembaga jaminan gadai, benda ada jaminan ada dalam penguasaan kreditor.

Kendala penjaminan kapal tersebut difasilitasi oleh BW dengan adanya lembaga jaminan hipotek, dalam Pasal 1162 BW, hipotek adalah suatu hak kebendaan atas benda-benda tak bergerak, untuk mengambil penggantian daripadanya bagi pelunasan bagi suatu perikatan. Konstruksi hukum ini hanya mengacu pada pembebanan benda tidak bergerak. Lingkup benda tidak bergerak tersebut tidak hanya atas kapal laut yang berukuran $20 \mathrm{~m}^{3}$, tetapi juga pada pembebanan atas tanah, namun hipotek atas tanah kini tidak berlaku lagi karena Buku II BW yang berkaitan dengan hipotek atas tanah telah tidak diberlakukan dengan hadirnya Undang-Undang No. 4 Tahun 1999 tentang Hak Tanggungan (yang selanjutnya disebut UUHT).

Istilah hipotek berasal dari hukum Romawi yaitu hypoteca atau dalam hukum Belanda terjemahannya adalah onderzetting yang artinya adalah penjaminan atau pembebanan. Gadai dan juga hipotek timbul melalui perjanjian yang dilakukan oleh para pihak dan merupakan lembaga jaminan kebendaan yang keberadaannya masing-masing diatur dalam Buku II Bab ke XX Pasal 1150 hingga Pasal 1161 dan bab XXI Pasal 1162 BW sampai dengan Pasal 1232 BW. Dalam Pasal 1162 BW tercantum pengertian hipotek, yaitu hipotek adalah suatu hak kebendaan atas bendabenda tidak bergerak untuk mengambil penggantian daripadanya bagi pelunasan suatu perikatan.

Batasan akan objek jaminan hipotek dijabarkan dalam Pasal 29 UUHT, bahwa hipotek dan crediet verband sepanjang menyangkut benda tanah dan segala sesuatu yang melekat dengan tanah dinyatakan tidak berlaku lagi. Keberadaan hipotek sendiri tetap eksis dengan objeknya yaitu benda tidak bergerak yang tidak menyangkut benda tanah, dan benda-benda yang terkait dengan tanah, contoh pesawat terbang, helikopter dan kapal laut, kapal laut sesuai dengan pengaturan Pasal 314 Kitab Undang-Undang Hukum Dagang (yang selanjutnya disebut KUHD). Kapal laut sebagai benda tidak bergerak dengan isi kotor sekurang-kurangnya $20 \mathrm{~m}^{3}$, dapat dijadikan obyek hipotek (Vide Pasal 46 ayat 1 UU No. 21 Tahun 1992). 
Hal ini juga diungkapkan oleh Moch. Isnaeni bahwa sesuai kewenangan yang dimiliki oleh pembentuk Undang-Undang, maka ditetapkanlah bahwa kapal dengan bobot kotor tidak kurang dari $20 \mathrm{~m}^{3}$, kalau dijadikan agunan, lembaga hipotek yang digunakan. Seluk-beluk jaminan kapal ini dalam KUHD (Wetboek van Koophandel yang masih berlaku atas dasar Pasal II Aturan Peralihan Undang-Undang Dasar 1945, untuk selanjutnya disebut $\mathrm{WvK}$ ) diatur mulai Pasal 314 sampai dengan 315e (Moch. Isnaeni, 1996:32).

Perjanjian hipotek ini merupakan bentuk jaminan khusus, yaitu timbul karena adanya perjanjian khusus dan melekat pada benda yang ditunjuk secara khusus oleh kreditor dan debitor. Maksudnya perjanjian yang diikuti perjanjian tersendiri yang merupakan tambahan (accessoir) yang dikaitkan dengan perjanjian pokok tersebut (Sri Soedewi Masjchoen Sofwan, 1980:37). Hal ini berarti kalau pihak yang bersangkutan tidak memenuhi kewajiban perikatannya, maka secara paksa, hukum dapat memerintahkan untuk jual lelang benda-benda milik orang tersebut guna mengganti pelunasan kewajiban perikatan yang dilalaikan itu (Moch. Isnaeni, 1996:76).

Oleh karena tidak ada perpindahan secara nyata kekuasaan atas benda, maka akta jaminan hipotek dan dokumen-dokumen pelengkapnya seperti sertifikat jaminan, dapat dijadikan bukti telah terbentuknya suatu kesepakatan. Untuk itu pihak debitor hipotek harus dinyatakan dengan sungguh-sungguh bahwa ia adalah orang yang bertindak bebas atas benda yang di hipotekkan, serta benda itu bebas dari segala beban. Dengan kata lain hipotek tidak bisa diletakkan selain oleh siapa yang berkuasa memindahtangankan benda yang dibebani, dan hipotek hanya dapat diletakkan pada benda-benda yang sudah ada, hipotek atas bendabenda yang akan ada dikemudian hari adalah batal (Vide Pasal 1168 jo. 1175 BW).

Dalam hal kapal laut dijadikan sebagai benda jaminan, Moch. Isnaeni menegaskan bahwa kapalkapal yang telah terdaftar dan akan dijadikan agunan, oleh Pasal 314 ayat 4 WvK dinyatakan dengan tegas tidak dapat dibebani dengan gadai, dan Pasal 1977 BW tidak dapat berlaku padanya (Moch. Isnaeni, 1996:76). Pasal 314 WvK ini menegaskan bahwa kapal Indonesia yang dibukukan dan telah didaftar dalam register kapal menurut peraturan yang berlaku, yaitu Pasal 158 Undang-Undang No. 17 Tahun 2008 tentang Pelayaran (selanjutnya disebut UU Pelayaran), apabila akan dijadikan agunan, maka lembaga jaminan hipotek yang dipergunakan, dapat dibebani hipotek.

Lembaga jaminan hipotek dikhususkan kepada kapal laut yang terdaftardengan berat kotor di atas
GT 7 (Grosse Tonnage) yang karenanya dinyatakan sebagai benda tidak bergerak. Menurut Pasal 310 KUHD, kapal laut adalah semua kapal yang dipakai untuk pelayaran di laut atau yang diperuntukkan untuk itu, sedangkan Pasal 1 angka 36 UU Pelayaran memberikan pengertian yang lebih luas mengenai kapal, yaitu kendaraan air dengan bentuk dan jenis tertentu, yang mana digerakkan dengan tenaga angin, tenaga mekanik, energi lainnya, ditarik atau ditunda, termasuk kendaraan yang berdaya dukung dinamis, kendaraan di bawah permukaan air, serta alat apung dan bangunan terapung yang tidak berpindah-pindah.

Disebutkan dalam Pasal 155 ayat 3 UU Pelayaran, bahwa sebelum digunakan dalam suatu pelayaran, setiap kapal laut wajib diukur untuk diterbitkannya surat ukur untuk kapal laut dengan ukuran isi kotor sekurang-kurangnya GT 7 (Tujuh Grosse Tonnage). Mengenai ketentuan pengukuran tersebut, dijelaskan lebih lanjut dalam Pasal 158 ayat 1 UU Pelayaran, bahwa kapal laut yang telah dilakukan pengukuran itu dapat didaftarkan di Indonesia pada Pejabat Pendaftar dan Pencatat Balik Nama Kapal yang ditetapkan oleh Menteri Perhubungan. Kapal laut yang dapat didaftar di Indonesia berdasarkan Pasal 158 ayat 2 UU Pelayaran adalah: a. Kapal dengan ukuran isi kotor sekurang-kurangnya GT 7 (Tujuh Grosse Tonnage); b. Dimiliki oleh warga negara Indonesia atau badan hukum yang didirikan berdasarkan hukum Indonesia dan berkedudukan di Indonesia; c. Kapal milik badan hukum Indonesia yang merupakan usaha patungan yang mayoritas sahamnya dimiliki oleh Warga Negara Indonesia.

Pendaftaran kapal tersebut dilakukan dengancara pembuatan akta pendaftaran dan juga dicatat dalam daftar kapal Indonesia, dan kemudian sebagai bukti kapal telah didaftar, pemilik diberikan surat tanda pendaftaran yang berfungsi pula sebagai bukti hak milik kapal yang didaftar dan pada kapal yang telah didaftar wajib dipasang tanda bukti pendaftaran, sebagaimana telah dijelaskan dalam Pasal 158 ayat 3, 4, 5 UU Pelayaran.

Kapal laut mempunyai berbagai aspek hukum yang cukup beragam misalnya saja pendaftaran, asuransi, kepemilikan, cara menjaminkannya, dan sebagainya, juga kapal laut mempunyai nilai ekonomis yang besar karena dapat dipergunakan untuk mendukung pengembangan armada pelayaran. Pengembangan armada pelayaran yang mana sifatnya membutuhkan banyak dana, dan pembiayaan yang dilakukan dengan berjangka serta membutuhkan dana investasi yang juga cukup besar itu dapat memperoleh pengadaan dana dengan jalan memperoleh jaminan kredit atau 
loan yang dibutuhkan, baik dari lembaga keuangan bank maupun nonbank. Dengan memahami aspekaspek dari pembebanan kapal laut sebagai objek jaminan, yang mana berdasarkan ukuran adalah $7 \mathrm{GT}$, mempunyai daya guna, nilai ekonomis, dan lain-lain, Wartini Soegeng menjabarkan jenis kapal laut yang ditujukan sebagai kegiatan perniagaan, dan karena itu kapal-kapal tersebut kerapkali dijadikan objek jaminan hipotek, jenis-jenis kapal laut tersebut antara lain: Kapal Pesiar; Kapal Penumpang; Kapal Ro-Ro; Kapal Barang atau Cargo Vessel; Kapal Tanker; Kapal Tunda; Peti Kemas atau Container Ship; dan Kapal Keruk. Dari penjabaran tersebut, Wartini Soegeng masih menambahkan mengenai jenis baru dari kapal, yaitu Cargo-Vessel with Limited Accomodation for Passengers. Dinamakan Cargo-Vessel with Limited Accomodation for Passengers bilamana sebuah kapal barang diberi ijin untuk mengangkat penumpang juga, namun hanya dalam jumlah terbatas (yaitu 12 orang). Keterbatasan disini bukanlah kelas dek, namun kelas kamar, maka bilamana terdapat akomodasi untuk lebih dari 12 orang penumpang, sebuah kapal dikategorikan dalam Cargo-Passengers Vessel (Wartini Soegeng, 1988:10-12).

Jenis-jenis kapal ini kerapkali digunakan oleh masyarakat Indonesia dewasa ini, dalam kegiatan bisnis yang juga kerapkali akhirnya dibebani dengan jaminan hipotek. Prosedur penjaminan hipotek atas kapal laut tentunya menggunakan suatu akta, akta tersebut dinamakan dengan akta hipotek, dan sesuai dengan pengaturan dalam Pasal 314 KUHD bahwa unsur-unsur yang tercantum dalam hipotek kapal adalah: Adanya hak kebendaan; Objeknya adalah kapal yang beratnya di atas $20 \mathrm{~m}^{3}$; Kapal tersebut harus dibukukan; Diberikan dengan akta otentik; dan Menjamin tagihan hutang.

Akta hipotek tersebut hanya dapat dikeluarkan oleh Pejabat Pendaftar dan Pencatat Balik Nama Kapal (selanjutnya disebut P3BK), sebagaimana telah ditentukan dalam UU Pelayaran. Namun produk akta hipotek yang dikeluarkan oleh P3BK tersebut dirasa kurang melindungi dan mewakili kepentingankepentingan para pihak, yaitu kreditor dan debitor, sehingga nantinya berpotensi menimbulkan problema hukum. Untuk mewakili dan melindungi kepentingankepentingan para pihak, maka dibuatlah Surat Kuasa Memasang Hipotek (yang selanjutnya disebut SKMH) yang dinilai lebih bisa merefleksikan keinginan para pihak. SKMH berisi sekumpulan keterangan dan janji-janji untuk para pihak, berbentuk akta, dan dibuat dihadapan Notaris. Setelah SKMH tersebut jadi, para pihak menghadap kepada P3BK.
Berdasarkan apa yang telah diuraikan tersebut di atas, permasalahan yang dikaji dalam penulisan ini adalah P3BK sebagai pembentuk akta hipotek serta implikasi janji-janji yang tertuang di dalam SKMH.

\section{PEMBAHASAN}

\section{Akta Hipotek sebagai Akta Otentik}

Proses pembebanan hipotek tentu saja dengan menggunakan akta hipotek, hal ini sebagaimana diatur dalam Pasal 1171 BW yaitu akta hipotek atas kapal laut termasuk jenis akta yang harus dibuat dengan akta otentik. Selanjutnya dinyatakan oleh Pasal 1 angka 1 jo. Pasal 15 ayat 1 Undang-Undang No. 30 Tahun 2004 tentang Jabatan Notaris (yang selanjutnya disebut UUJN), mengenai akta otentik disebutkan bahwa notaris lah yang berwenang membuatnya. Notaris adalah pejabat yang berwenang membuat akta otentik mengenai semua perbuatan, perjanjian, dan juga ketetapan yang diharuskan oleh peraturan perundang-undangan dan/atau yang dikehendaki oleh yang berkepentingan untuk dinyatakan dalam akta otentik, menjamin kepastian tanggal pembuatan akta, menyimpan akta, memberikan grosse, salinan dan kutipan akta sepanjang pembuatan akta-akta itu tidak juga ditugaskan atau dikecualikan kepada pejabat lain atau orang lain yang ditetapkan oleh undang-undang.

Disebutkan juga dalam Pasal 1868 BW bahwa suatu akta otentik ialah suatu akta yang di dalam bentuk yang ditentukan oleh undang-undang, dibuat oleh atau di hadapan pegawai-pegawai umum yang berkuasa untuk itu di tempat dimana akta dibuatnya. Hal ini sebenarnya tidak sejalan dengan pengaturan dalam Pasal 60 ayat 2 UU Pelayaran, bahwasanya pembebanan hipotek atas kapal laut dilakukan dengan pembuatan akta hipotek oleh P3BK.

Rachmadi Usman berpendapat mengenai akta otentik ini serta kewenangan dalam pembuatannya, bahwa akta hipotek merupakan akta otentik yang dibuat oleh atau dihadapan notaris sebagai pejabat umum (Rachmadi Usman, 2008:269). Demikian juga pendapat J. Satrio bahwa akta yang bisa dikeluarkan (untuk hipotek kapal) dalam bentuk grosse adalah akta otentik. Otentik dalam Pasal 1171 BW sebenarnya adalah dalam arti kata notariil (J. Satrio 2007:271). Mengenai permasalahan kewenangan akta otentik ini, Habib Adjie juga mengemukakan pendapatnya mengenai kewenangan ini, yaitu wewenang (atau yang biasa digunakan istilah kewenangan) merupakan suatu tindakan hukum yang diatur dan diberikan pada suatu jabatan berdasarkan peraturan perundangundangan yang berlaku yang mengatur jabatan yang bersangkutan (Habib Adjie, 2008:77). 
Dalam hal seperti ini sebenarnya notaris telah dikonstruksikan sebagai pejabat yang berwenang membuat akta otentik sepanjang diperintahkan oleh undang-undang atau undang-undang menentukan lain yang dikehendaki oleh para pihak agar perbuatan hukumnya dituangkan dalam suatu akta notaris.

Meskipun dalam UUJN tegas ditentukan bahwa notaris berwenang untuk membuat akta otentik yang mempunyai kekuatan hukum sempurna, namun walau demikian akta otentik tidak harus selalu dibuat oleh notaris, karena sesungguhnya akta otentik merupakan suatu akta yang ditentukan oleh undang-undang, dibuat oleh pegawai-pegawai umum yang berkuasa atas itu di tempat mana akta dibuatnya.

Dengan ini dapat dipahami bahwa akta hipotek kapal laut yang dibuat oleh P3BK dapat dikategorikan sebagai akta otentik, karena sebenarnya akta itu telah memenuhi persyaratan sebagai akta otentik, yaitu dalam bentuk yang ditentukan oleh UU Pelayaran dan dibuat oleh pejabat atau pegawai umum yang berkuasa untuk itu di tempat mana akta dibuatnya (ditentukan oleh UU Pelayaran). Lagipula berdasarkan asas hukum Lex Specialis Derogat Legi Generalis UU Pelayaran sifatnya lebih khusus mengatur mengenai pembuatan akta hipotek ini.

Habib Adjie menyatakan bahwa tulisan-tulisan otentik berupa akta otentik, yang dibuat dalam bentuk yang sudah ditentukan oleh undang-undang, dibuat dihadapan pejabat-pejabat atau pegawai umum yang diberi wewenang dan di tempat dimana akta tersebut dibuat, dan akta otentik tidak saja dapat dibuat oleh notaris (Habib Adjie, 2008:120). Dengan ini jelas dimungkinkan bahwa akta yang dibuat oleh pejabat selain notaris juga merupakan akta otentik.

Lebih lengkapnya mengenai akta otentik ini juga diungkapkan oleh C.A. Kraan, bahwa akta otentik mempunyai ciri sebagai berikut: Suatu tulisan, dibuat dengan sengaja dibuat semata-mata untuk dijadikan alat bukti atau suatu bukti dari keadaan sebagaimana disebutkan di dalam tulisan dibuat dan dinyatakan oleh pejabat yang berwenang. Tulisan tersebut turut ditandatangani oleh atau hanya ditandatangani oleh pejabat bersangkutan saja; Suatu tulisan sampai ada bukti sebaliknya, dianggap berasal dari pejabat yang berwenang; Ketentuan perundang-undangan yang harus dipenuhi, ketentuan tersebut mengatur tata cara pembuatannya (sekurangnya memuat ketentuan mengenai tanggal, tempat dibuatnya akta suatu tulisan, nama dan juga kedudukan atau jabatan pejabat yang membuatnya data dimana dapat diketahui mengenai hal-hal tersebut); Seorang pejabat yang diangkat oleh negara dan mempunyai sifat juga pekerjaan yang mandiri (onafhankelijk-independence) serta tidak memihak (onpatijdigheid-impartiality) pada waktu menjalankan jabatannya; Pernyataan dari fakta atau tindakan yang disebutkan oleh pejabat adalah hubungan hukum di bidang hukum privat (C.A. Kraan dalam Habib Adjie, 2008:27). Berdasar penjabaran di atas, maka jelas bahwa secara hukum, akta otentik yang dibuat oleh Pejabat P3BK mempunyai kekuatan hukum yang sempurna, dan tentu saja mempunyai kekuatan pembuktian yang sempurna pula.

Pengukuran mengenai kekuatan pembuktian ini dikemukakan oleh Jusuf Patrianto Tjahjono bahwa nilai kekuatan pembuktian yang melekat pada akta otentik diatur dalam Pasal 1870 BW jo. Pasal 285 RGB adalah sempurna atau volledig bewijskracht dan mengikat atau bidende bewijskracht, sehingga akta otentik dapat berdiri sendiri tanpa memerlukan bantuan atau dukungan alat bukti yang lain, dengan kata lain akta otentik yang berdiri sendiri menurut hukum telah memenuhi ketentuan batas minimal pembuktian (Jusuf Patrianto Tjahjono, 2009:5).

\section{Peran Notaris dan Keperluan SKMH Sebagai Langkah Pembebanan Hipotek}

Memahami bahwa dalam pembuatan akta hipotek dilakukan oleh Pejabat Pendaftar dan Pencatat Balik Nama Kapal, namun juga notaris tidak semata-mata hilang peranan dalam pembebanan hipotek atas kapal laut ini, notaris tetap dapat membuat akta pendukung akta hipotek tersebut (sebagaimana notaris membuat akta fidusia, akta jaminan resi gudang, akta gadai, akta borgtocht, dan lainnya), yang kemudian dinamakan dengan SKMH. Keduanya pun mempunyai persamaan dan perbedaan yang menonjol. Dengan melihat dan memahami substansi SKMH dan akta hipotek yang dibuat oleh P3BK, maka bila dilihat dari substansinya, keduanya sama-sama mencantumkan hal berikut ini: Pertama, Menerangkan pihak yang berpiutang atau kreditor dan berutang atau debitor, adalah bagian awal yang mutlak keberadaannya dalam suatu akta karena akan menerangkan identitas seperti nama, tempat tanggal lahir, kewarganegaraan, pekerjaan, jabatan, kedudukan, tempat tinggal dari para penghadap dan/ atau orang yang mereka wakili termasuk keterangan mengenai kedudukan bertindak penghadap, ataupun untuk memberikan keterangan atas permintaan siapa dibuat akta yang dimaksud; Kedua, Nilai penjaminan hipotek, dalam kedua akta dicantumkan nilai dari penjaminan barang yang diikat dengan hipotek, hal ini ditujukan karena seringkali terjadi bahwa nilai barang jaminan (kapal yang diikat hipotek) berbeda dengan besarnya nilai penjaminannya, yang biasanya 
nilai penjaminannya lebih rendah dari nilai nilai sebenarnya barang tersebut; Ketiga, Jenis, deskripsi dan identitas objek barang jaminan (kapal laut), yang uraiannya berupa nama kapal, jumlah, surat ukur, panjang kapal, lebar, dalam, tonas, buatan, tahun, dan sebagainya; Keempat, Perjanjian kredit yang menjadi pokok perjanjian. Sebagaimana telah diketahui bahwa perjanjian hipotek ini merupakan perjanjian accesoire dari perjanjian pokok kredit sebelumnya, maka dari itu adalah suatu keharusan untuk dicantumkan perjanjian induknya tersebut; Kelima, Pernyataan tidak adanya duplikasi jaminan, yang berarti meyakinkan kedua belah pihak bahwa kapal laut yang sedang dipasang hipotek, tidak sedang dibebani dengan hipotek lain, tidak terbebani dan bebas dari sita manapun.

Melihat keduanya, antara SKMH dan akta buatan P3BK, tentu ada perbedaan, hal ini terutama karena seorang notaris mempunyai latar belakang yang sangat berbeda dengan pembuat akta dari P3BK, seorang notaris terbentuk dengan ilmu yang dimiliki dan akan membuat akta dengan menggunakan standard dan prinsip-prinsip pembuatan akta yang berlaku dalam standard profesionalitasnya. Inilah dasar yang membedakan SKMH dengan akta hipotek hasil dari P3BK tersebut. Sebagai perbedaan keduanya, dalam SKMH mencantumkan klausula-klausula atau janjijanji sebagai berikut:

Pertama, Beding van Eigenmachtige Verkoop atau janji untuk menjual atas kemauan sendiri. Berisi suatu janji dimana pemegang hipotek pertama diberi kekuasaan untuk melakukan penjualan di muka umum atas barang yang dijadikan objek jaminan tanpa harus melalui perantara pengadilan, bilamana penerima kredit (debitor) tidak memenuhi kewajiban dalam perjanjian kredit.

Kedua, Huur Beding atau disebut janji sewa. Berisi mengenai janji yang menyatakan bahwa pemilik barang yang dijaminkan harus meminta persetujuan terlebih dahulu kepada kreditor jika akan menyewakan barang jaminan kepada pihak lain.

Ketiga, Assurantie Beding atau janji asuransi. Berisi mengenai kreditor yang nanti akan menerima uang dari hasil pembayaran klaim asuransi untuk diperhitungkan dengan hutang debitor kepada kreditor jika terjadi resiko kerugian terhadap kapal laut yang dibebani hipotek, dan pembayaran premi asuransinya tetap menjadi beban penerima kredit (debitor). Disini kreditor perlu mencantumkan Banker's Clause agar ada kewajiban dari pihak asuransi untuk membayar langsung ke kreditor. Pengertian Banker's Clause ini adalah suatu klausul yang menyatakan bahwa kreditor sebagai pihak perjanjian yang menerima santunan asuransi bilamana terjadi kerugian atas musnahnya benda yang menjadi objek jaminan yang dipertanggungkan dalam klaim asuransi. Apabila pada waktu debitor melakukan permohonan kredit obyek jaminan tersebut belum diasuransikan, maka bank harus memberitahukan kepada perusahaan asuransi untuk mencantumkan Banker's Clause. Maka dengan adanya hal ini, kerapkali kreditor memperjanjikan Banker's Clause dengan mana perusahaan asuransi terikat untuk membayarkan santunan asuransi kepada kreditor.

Keempat, Beding Van Niet Zuivering atau janji untuk tidak dibersihkan. Berisi mengenai pemberian perlindungan kepada pemegang hipotek untuk tidak melakukan pencoretan hipotek atas barang jaminan kredit yang telah dibebani hipotek, yaitu dalam hal kapal dijual secara sukarela dengan harga di bawah nilai hipotek, sedangkan pinjaman belum sepenuhnya terlunasi dengan harga kapal tersebut di atas.

Kelima, Janji pengosongan. Janji pengosongan ini berisi ketentuan bahwa pemilik kapal dengan biaya sendiri akan mengosongkan kapal yang dijaminkan tersebut jika kreditor memandang perlu untuk menjual kapal tersebut dalam rangka penyelesaian kredit.

Keenam, Janji hipotek berlanjut. Merupakan janji yang berisi bahwa hipotek berlaku atas hutang yang timbul karena perjanjian kredit yang sudah ada beserta perubahan dan/atau perpanjangannya maupun hutang yang timbul karena perjanjian kredit yang dibuat kemudian.

Ketujuh, Klausula tentang penyimpanan Grosse Akta Pendaftaran Kapal Laut asli. Janji ini berisi pernyataan bahwa pemberi hipotek memberi kuasa dengan hak substitusi pada kreditor untuk menerima dan menyimpan asli grosse tersebut setelah dilakukan pencatatan dalam Daftar Hipotek pada Daftar Induk Pendaftaran Kapal sampai kredit yang dijamin dengan hipotek tersebut dinyatakan lunas oleh bank, atau bila sudah tidak dijadikan sebagai jaminan kredit.

Kedelapan, Klausula perlekatan. Klausula ini berisi pernyataan bahwa hipotek itu meliputi kapal dengan segala peralatan (navigasi, elektronik, dan lainnya) baik yang sudah ada maupun yang akan ditempatkan atau diletakkan yang menurut sifat dan peruntukannya merupakan bagian yang tidak terpisah dari kapal tersebut.

Kesembilan, Janji tidak mengubah bentuk. Janji ini berisi mengenai pernyataan bahwa jika pemberi hipotek akan mengubah tata susunan objek hipotek (yang meliputi keseluruhan objek seperti tambahan susunan kabin, dll) diharuskan mendapat persetujuan tertulis lebih dahulu dari penerima hipotek. 
Klausula dan janji-janji tersebut merupakan bagian dalam SKMH, dan dibuat secara mendetail, lebih lagi juga dicantumkannya saksi dalam SKMH, saksi ini memiliki peranan penting, yaitu dimaksudkan sebagai pihak luar perjanjian yang ikut serta mengetahui adanya hubungan hukum yang dibuat oleh para pihak, sehingga keberadaan akta ini akan menjadi bukti sebagai akta otentik jika dikemudian hari terdapat sengketa. Dengan demikian apa yang tertuang dalam SKMH tentunya akan dirasakan dapat lebih menjamin kepentingan dari para pihak, dan mengakomodasi keinginan para pihak (debitor dan kreditor).

Sedangkan akta hipotek yang dimiliki oleh P3BK hanya berisi hal-hal yang bersifat umum saja, antara lain hanya mencantumkan identitas kapal, jumlah penjaminan, status pendaftaran, lama penjaminan, dan pernyataan tidak adanya duplikasi penjaminan. Sudah barang tentu hal semacam ini kurang melindungi kepentingan para pihak karena banyaknya celah yang bisa menimbulkan problema hukum dan berbagai kecurangan dari pihak yang tidak beritikad baik. Hal ini tentunya terjadi karena pembuatan dari dokumen penjaminan hipotek tidak ditugaskan pada orang yang benar-benar berpengetahuan dan mempelajari sedalam-dalamnya tentang hal ini yaitu notaris, namun pembuatan dokumen penjaminan hipotek dilimpahkan kewenangannya kepada P3BK.

Inilah fungsi dan peranan SKMH sebagai bagian dari proses pembebanan hipotek kapal laut. Agar akta hipotek lebih mempunyai kekuatan mengikat dan juga memberikan kepastian atau perlindungan hukum kepada pemegangnya (terutama kreditor). SKMH lebih sebagai jembatan yang merealisasikan keinginan debitor dan kreditor yang tidak terpenuhi oleh akta buatan P3BK. SKMH adalah pelengkap akta pejabat terkait tersebut. Dan SKMH juga kerapkali digunakan untuk menghindari tidak hadirnya atau sulitnya menghadirkan kembali debitor pada saat penandatanganan akta pembebanan hipotek sehingga berdasarkan SKMH tersebut debitor memberikan kuasa pada kreditor untuk pemasangan hipoteknya pada Pejabat Pendaftar dan Pencatat Balik Nama Kapal, dengan adanya hal ini dapat lebih menghemat waktu. Hingga kini, dalam prakteknya, para pihak cenderung untuk membuat SKMH terlebih dahulu kepada notaris sebelum dilanjutkan untuk pembuatan akta hipotek pada P3BK. Hal ini semakin memberi makna bahwa akta oleh P3BK dirasa kurang dapat mewakili kepentingan para pihak bilamana tidak didampingi dengan SKMH.

SKMH berperan sebagai pelengkap akta hipotek yang dibuat oleh P3BK, tentunya tidak dapat berdiri sendiri. Setelah dibuat SKMH, selanjutnya pejabat pendaftar cukup mencantumkan ke dalam akta hipotek yang dibuatnya, kemudian dianggap apa yang termuat dalam SKMH juga termuat dalam akta hipotek yang dimaksud. Dalam akta hipotek akan dicantumkan bahwa dalam pembuatan akta hipotek, perbuatan hukum tersebut berasarkan pada akta SKMH, nama notaris yang membuatnya, nomor, tanggal, dan nilai hutang yang tercantum dalam perjanjian kredit yang dimuat juga dalam SKMH, serta syarat-syarat yang ditetapkan sendiri oleh kreditor, kemudian terbitlah yang dinamakan grosse akta hipotek. Grosse akta berisi dokumen-dokumen termasuk nomor registrasi SKMH, dan grosse akta tersebut untuk disimpan kreditor.

\section{Hipotek sebagai Jaminan Kebendaan}

Hipotek sebagai jaminan kebendaan yaitu jaminan yang objeknya benda milik debitor yang mana diikat secara khusus dan memerlukan pendaftaran, dan akan menimbulkan hak kebendaan yang sifatnya mutlak atau zakelijke zekerheidsrechten dan juga bersifat memberikan kedudukan preferen kepada para kreditornya, sehingga hak jaminan kebendaan tersebut memiliki beberapa keunggulan bila dibandingkan dengan hak jaminan lainnya termasuk juga jaminan perorangan. Timbulnya hak kebendaan harus melalui perjanjian accessoir yaitu suatu perjanjian tambahan dari perjanjian awal (induknya), dengan kata lain harus diperjanjikan terlebih dulu mengenai benda yang akan dijaminkan secara khusus (Pasal 1132 BW), sebagaimana dikemukakan oleh Sri Soedewi Masjchoen Sofwan, yaitu jaminan yang berupa hak mutlak atas suatu benda, yang mempunyai ciri-ciri mempunyai hubungan langsung atas benda tertentu, dapat dipertahankan pada siapa pun, selalu mengikuti bendanya atau droid de suite dan dapat dialihkan (Sri Soedewi Masjchoen Sofyan, 1980:46-47).

Hak kebendaan mempunyai asas-asas tersendiri yang berlaku daripadanya, Sri Soedewi Machsoen Sofwan menyebutkan bahwa sekurangnya ada 10 (sepuluh) asas umum hak kebendaan, antara lain: Hukum kebendaan merupan hukum yang bersifat memaksa; Hak kebendaan dapat dipindahtangankan; Individualiteit; Totaliteit; Onsplitsbaarheid atau asas tidak dapat dipisahkan; Prioriteit (asas prioritas); Asas Vermenging atau percampuran; Asas Publicitiet; Asas perlakuan yang berbeda atas kebendaan yang bergerak dan juga kebendaan yang tidak bergerak; Adanya sifat perjanjian dalam setiap pengadaan atau pembentukan hak kebendaan (Sri Soedewi Machsoen Sofwan, 1975:36-40). 
Hipotek sebagai hak kebendaan daripada jaminan kebendaan juga mewakili asas dasar hak kebendaan di atas, dijabarkan oleh Gunawan Widjaja bahwa hipotek memiliki sifat khusus, yaitu: Hipotek bersifat memaksa atau absolute; Hipotek dapat beralih atau dipindahtangankan; Hipotek bersifat individualitet; Hipotek bersifat menyeluruh atau totaliteit; Hipotek tidak dapat dipisahkan atau onsplitsbaarheid; Hipotek berjenjang (ada prioritas yang satu atas yang lainnya); Hipotek wajib untuk diumumkan; Hipotek mengikuti bendanya atau droit de suite (Pasal 1136 dan 1198 $\mathrm{BW}$ ); Bersifat mendahulu atau droit de preference (Pasal 1132 BW); Hipotek sebagai Jura in re Alinea atau yang terbatas (Gunawan Widjaja, 2005:207).

Sesuai dengan karakter jaminan kebendaan, maka kreditor penerima hipotek yang dalam hal ini adalah pemegang hipotek atas kapal laut memiliki kepastian hukum serta kedudukan yang cukup aman dan kuat dalam rangka memperoleh kembali akan pelunasan piutangnya apabila sewaktu-waktu debitor melakukan wanprestasi. Kreditor pemegang hipotek atas kapal laut memiliki hak kebendaan yang lahir pada saat didaftar dalam suatu register umum dan mempunyai ciri-ciri istimewa hipotek, sebagaimana diungkapkan oleh Moch. Isnaeni bahwa perjanjian jaminan hipotek yang sering menyertai pemberian fasilitas kredit perbankan, akan melahirkan hak-hak kebendaan bagi kreditornya. Hak kebendaan ini memiliki ciri-ciri yang tangguh misalnya hak itu dapat ditegakkan terhadap siapa pun atau mutlak, ada droit de suite, memiliki preferensi, berazas prioritas dan mempunyai prinsip spesialitas (Moch. Isnaeni, 1996:179).

\section{Implikasi Janji-janji dalam Perjanjian Hipotek terhadap Pihak Ketiga}

Sebagaimana pengikatan hak tanggungan, dalam hipotek juga dicantumkan klausula-klausula yang dapat memperkuat keberadaan daripada penjaminan hipotek ini seperti janji atau syarat dalam SKMH yang telah dijabarkan di atas, antara lain: Beding Van Eigenmactige Verkoop atau janji untuk menjual atas kemauan sendiri; Huur Beding atau janji sewa; Janji Pengosongan; Assurantie Beding atau janji asuransi; Beding Van Niet Zuivering atau janji tidak dibersihkan; Janji Hipotek Berlanjut atau kredit hipotek; Klausula Menyimpan Asli Grosse Akta Pendaftaran Kapal; Klausula Perlekatan; Janji Tidak Mengubah Bentuk

Penjaminan hipotek, tentu harus disertai dengan adanya pendaftaran, yaitu harus didaftarkan kepada instansi yang berwenang dan dicantumkan dalam register umum, setelah akta hipotek tersebut selesai dibuat dan ditandatangani, maka hipotek kapal laut tersebut dicatatkan dalam daftar hipotek pada daftar induk pendaftaran kapal. Mengenai arti pentingnya pendaftaran dilakukan bagi jaminan hipotek ini adalah konsekuensi sebagai hak kebendaan, pendaftaran dalam register umum merupakan suatu keharusan. Hal itu semua merupakan kelebihan-kelebihan yang melekat pada hak hipotek sebagai hak kebendaan (Moch. Isnaeni, 1996:179). Sebagai bukti adanya jaminan hipotek pada suatu obyek kpal laut, maka akan diterbitkan grosse akta hipotek. Diungkapkan oleh Rachmadi Usman bahwa pembebanan hipotek tersebut wajib didaftar dalam register umum yang disediakan untuk itu di tempat kantor pendaftaran yang bersangkutan, yang dilakukan oleh pegawai balik nama (Rahmadi Usman, 2008:266).

Pendaftaran hipotek dalam suatu register umum ini diatur dalam Pasal 1179 BW, dan bilamana tidak dilakukan, tidak akan mempunyai kekuatan apa pun. Saat ini, keseluruhan rangkaian proses pembuatan, pendaftaran, sampai dengan pengeluaran grosse akta hipotek kapal laut, semuanya dilakukan oleh instansi yang berwenang. Instansi tersebut yang membawahi lingkup pelayaran dan/atau perkapalan, dalam hal ini adalah Departemen Perhubungan Direktorat Jendral Perhubungan Laut atau disebut juga Syah Bandar (Rahmadi Usman, 2008:266).

Pendaftaran ditujukan juga sebagai pemenuhan asas publisitas, salah satu ciri jaminan hutang modern adalah dengan terpenuhinya unsur publisitas. Dengan maksud semakin terpublikasi jaminan hutang, akan semakin baik sehingga kreditor atau khalayak ramai dapat mengetahuinya atau mempunyai akses untuk mengetahui informasi-informasi penting di sekitar jaminan hutang tersebut.

Pendaftaran sebagai asas publisitas ini menjadi semakin penting terhadap jaminan-jaminan hutang yang mana fisik objek jaminannya tidak diserahkan terhadap kreditor. Oleh karena itu, Rachmadi Usman menambahkan, kewajiban pendaftaran penjaminan hipotek kepada instansi yang berwenang merupakan salah satu perwujudan asas publisitas, dan diharapkan agar tidak ada para pihak yang beritikad buruk (baik debitor maupun kreditor), dengan menghipotekkan sekali lagi atau bahkan menjual barang objek jaminan (Munir Fuady, 2003:30). Terlebih lagi, daftar kapal yang ada di kantor pendaftaran kapal itu bersifat terbuka atau openbaarheid sehingga setiap orang dapat melihat pendaftaran suatu kapal, bahkan dapat meminta salinan akta-akta kapal tertentu kepada Pegawai Pendaftar Kapal sehingga apabila seseorang hendak membeli kapal tersebut, atau mempunyai kepentingan lain, dapat mengetahui hal-hal tentang 
kapal tersebut, misalnya apakah terbebani dengan hipotek, ataukah tidak.

Dari uraian di atas, dapat dipahami bahwa sesuai yang disyaratkan oleh Pasal 1179 BW, pendaftaran hipotek, maupun pendaftaran kapal merupakan salah satu aspek yang diharuskan dalam sistem pengaturan pelayaran sebagai wujud dari asas publisitas. Asas publisitas ini dimaksudkan agar dapat mempunyai akibat hukum terhadap pihak ketiga. Perlindungan yang timbul dalam hal didaftarkannya perjanjian hipotek ini berlaku untuk para pihak, yaitu debitor dan kreditor, juga kepada pihak ketiga.

Tidak hanya keterangan akan status kapal, berat, jenis dan juga dibebaninya kapal akan jaminan hipotek yang melahirkan kewaspadaan dalam membeli atau membebani dengan hak jaminan hipotek lain dalam suatu kapal yang tentunya karena terteranya janjijanji dalam SKMH yang telah didaftarkan tersebut, hal lain yang juga bertalian dengan implikasi adanya janji-janji dalam SKMH tersebut adalah membuat pihak ketiga lebih waspada karena bila debitor ingkar janji atau pailit, maka pemegang kreditor hipotek ini mempunyai kuasa untuk menjual sendiri objek hipotek tanpa membutuhkan persetujuan dari debitor dan tidak perlu meminta penetapan pengadilan apabila akan melakukan eksekusi atas benda jaminan, hal ini dinamakan kuasa menjual, dan diatur dalam Pasal 1178 BW, yaitu diperkenankan untuk diperjanjikan sebelumnya antara kreditor dan debitor, bila tidak dilunasi hutang, maka dapat mengambil pelunasan secara mandiri.

Hal lain yang juga merupakan hal utama yang menjadi keuntungan kreditor akan adanya janji-janji tersebut adalah saat adanya force majeure terhadap objek jaminan hipotek, dimana sudah pasti kreditor tersebut tidak lagi mendapatkan preferensinya dalam mendapatkan pelunasan hutang, dengan kata lain bukan lagi menjadi kreditor preferen, namun menjadi konkuren. Meskipun menjadi kreditor konkuren, namun tetap pelunasan hutangnya akan didahulukan sebagaimana kreditor preferen, karena adanya janjijanji dalam SKMH tersebut yang menjelaskan tentang adanya preferensi pelunasan hutang. Dalam bentuk ini implikasi janji-janji tersebut mengikat kepada pihak ketiga, agar semakin waspada dan memahami. Bahwa meskipun suatu waktu posisi kreditor hipotek menjadi konkuren, namun sifat preferensi terhadap pelunasan hutangnya masih ada karena janji-janji tersebut.

Implikasi terhadap pihak ketiga akan janji-janji dalam SKMH ini terlahir saat adanya pendaftaran, dengan adanya asas publisitas maka khalayak menjadi tahu atau dianggap tahu bagaimana status kapal yang bersangkutan, seperti halnya juga dengan adanya kuasa menjual sendiri (yaitu pihak ketiga pun lebih waspada akan pembebanan hutang dengan objek jaminan yang sama), juga janji perlekatan (dimana ini juga sebagai wujud hipotek tidak dapat dibagi-bagi), atau janji tidak merubah bentuk (pihak pembangun kapal juga harus tahu bahwa desain kapal selanjutnya harus ada persetujuan dari kreditor), atau juga janji sewa yang tentu saja pihak ketiga sebagai penyewa dianggap tahu bahwa kapal itu dibebani hipotek, dan harus dengan persetujuan dari kreditor terlebih dahulu, dan janji asuransi secara otomatis akan merangkul pihak ketiga yaitu pihak asuransi. Perusahaan asuransi diwajibkan untuk mengikuti aturan-aturan dalam UU Pelayaran selain mentaati dan menjalankan kebijakan yang telah mereka buat sendiri.

Tentu saja adanya implikasi kepada pihak ketiga atas janji-janji ini tidaklah bertujuan untuk merugikan atau menguntungkan pihak ketiga. Bertalian dengan hal ini, janji-janji yang tertulis dalam SKMH itu bertujuan untuk melindungi pihak kreditor, debitor, juga pihak ketiga, oleh karena itu perwujudannya adalah dengan menggunakan asas publisitas yang nantinya secara otomatis mengikat juga pihak-pihak di luar perjanjian, tepatnya pihak-pihak yang mempunyai dan ingin mempunyai kepentingan atas objek jaminan tersebut.

Bilamana setelah ada publikasi dan pihak ketiga lalai memperhatikan bahwa adanya register akan kapal yang bersangkutan, maka ia harus memikul sendiri resiko akibat kelalaiannya itu (J. Satrio, 1996:245). Dengan demikian, janji-janji dalam SKMH yang telah didaftarkan tersebut memiliki kekuatan mengikat terhadap pihak ketiga atau pihak ketiga menjadi terikat karenanya, dengan konsekuensi wajib menghormati hak kebendaan yang bersangkutan.

\section{PENUTUP \\ Kesimpulan}

Jaminan hipotek kapal laut dilakukan dengan menggunakan SKMH terlebih dahulu yang berisi mengenai janji-janji yang disepakati oleh kreditor dan debitor sebagai perlindungan masing-masing pihak, hal ini karena dirasa akta hipotek yang dibuat oleh P3BK kurang dapat mewakili dan melindungi kepentingan para pihak. Dan dengan adanya asas publisitas yang mana disyaratkan untuk penjaminan hipotek, janji-janji yang tertera dalam SKMH tersebut akan mengikat pihak ketiga dengan sendirinya dan berimplikasi pada pihak ketiga yang mana adalah masyarakat, calon kreditor hipotek lain, atau juga perusahaan asuransi. Implikasi ini antara lain sebagai 
perlindungan bagi pihak ketiga, dan juga para pihak lain didalam perjanjian jaminan hipotek kapal laut tersebut.

\section{Rekomendasi}

Karena kualitas keilmuan dari notaris yang juga masih sangat dibutuhkan, dan dengan bukti SKMH yang mana hanya dapat dibuat oleh notaris, maka diharapkan agar menjadikan notaris itu berwenang dalam membuat akta hipotek yang saat ini hanya dapat dibuat oleh P3BK, dengan ini harus ditentukan secara khusus mengenai kewenangan notaris sebagai pejabat umum yang dapat membuat akta hipotek. Dengan pertimbangan kegiatan bisnis transportasi laut juga sedang berkembang saat ini, penyempurnaan aturan dengan adanya peraturan setingkat undangundang yang khusus mengatur tentang hipotek akan melahirkan unifikasi hukum tentang lembaga jaminan hipotek, jadi peraturannya tidak tersebar dan semakin mudah dimengerti oleh khalayak. Penyempurnaan pada grosse akta tentunya juga dapat menambah kekuatan hukum dari keseluruhan dokumen hipotek, dan dalam grosse tersebut juga harus disalin atau dilampirkan dokumen-dokumen yang ada, terutama untuk pencantuman SKMH kedalam akta hipotek, sebaiknya tidak hanya dituliskan nomor registrasinya saja.

\section{DAFTAR PUSTAKA}

Buku:

Adjie, Habib, 2008, Hukum Notaris Indonesia: Tafsir Tematik terhadap Undang-Undang No. 30 Tahun 2004 tentang Jabatan Notaris, Bandung: Refika Aditama.

Agoes, Etty R., 1991, Konvensi Hukum Laut 1982 dan Masalah Pengaturan Hak Lintas Kapal Asing, Bandung: Abardin.
Fuady, Munir, 2003, Jaminan Fiducia, Cetakan Kedua Revisi, Bandung: Citra Aditya Bakti.

Isnaeni, Moch., 1996, Hipotek Pesawat Udara di Indonesia, Surabaya: Dharma Muda.

Kraan, C.A., 1984, De Authentieke Akte, Arnhem: Gouda Quint BV.

Patrianto, Jusuf T., 2009, Kedudukan Akta Otentik dalam Sistem Hukum Pembuktian.

Satrio J., 1996, Hukum Jaminan Hak-Hak Kebendaan, Bandung: Citra Aditya Bakti. , 2007, Hukum Jaminan, Hak Jaminan Kebendaan, Bandung: Citra Aditya Bakti.

Soegeng, Wartini, 1988, Pendaftaran Kapal Laut di Indonesia, Bandung: Eresco.

Sofwan, Sri Soedewi, 1980, Hukum Jaminan di Indonesia: Pokok-Pokok Hukum Jaminan dan Jaminan Perorangan, Yogyakarta: Liberty Offset.

Usman, Rachmadi, 2008, Hukum Jaminan Keperdataan, Jakarta: Sinar Grafika.

Kitab Undang-Undang Hukum Dagang (KUHD).

Burgerlijk Wetboek (BW).

\section{Peraturan Perundang-undangan:}

Undang-Undang No. 21 Tahun 1992 tentang Perkapalan.

Undang-Undang No. 30 Tahun 2004 tentang Jabatan Notaris.

Undang-Undang No. 4 Tahun 1999 tentang Hak Tanggungan.

Undang-Undang No. 17 Tahun 2008 tentang Pelayaran.

\section{Internet:}

Supriyono, Hadi, Jenis-Jenis Kapal Niaga, http:// crewagent.plusadvisor.com/ilmu-pelayaran/330jenis-jenis-kapal-niaga-di-indonesia (diakses tgl. 11/01/2012). 